\title{
A Clinical Study of Circulating Cellular and Humoral Biomarkers Involved in Bone Regeneration Following Traumatic Lesions
}

\author{
Hans Gottlieb, ${ }^{1,2}$, Tobias W. Klausen², Martin Boegsted ${ }^{3}$, Bo S. Olsen ${ }^{1}$, Gunnar S. Lausten ${ }^{1}$, Jens Kastrup ${ }^{4}$, Julia S. Johansen ${ }^{5}$, Mette $^{2}$ \\ Nyegaard $^{3}$, Karen Dybkaer ${ }^{3}$ and Hans E. Johnsen ${ }^{2,3 *}$
}

1Department of Orthopaedic Surgery

2The Research Laboratory, Department of Hematology Herlev Hospital, University of Copenhagen, Denmark

3The Research Laboratory, Department of Hematology, Aalborg Hospital, Aarhus University Hospital, Aalborg, Denmark

4Medical Department B, Cardiac Catheterization Laboratory, The Heart Centre, Rigshospitalet, University of Copenhagen, Denmark

5Department of Rheumatology, Herlev Hospital, University of Copenhagen, Denmark

\section{Abstract}

Background: Fracture healing includes formation of cartilage, blood vessels and bone, which involves circulating progenitor cells, cytokines and growth factors in a complex homeostasis of tissue regeneration. Here we describe a clinical study of circulating cellular and humoral variables by a time dependent multiparametric approach following traumatic lesions.

Materials and Methods: Two prospective cohorts of 50 patients, with ankle- or hip fracture (cohort 1) or planned hip replacements (cohort 2) were studied as was age matched healthy controls. Blood samples were timely collected during the post traumatic period and analysed for i) non-haematopoietic (CD45 ${ }^{\text {neg }}$ ) mesenchymal subsets by multiparametric flow cytometry (MFC), ii) global gene expression profiling (GEP) by micro array and iii) serum inflammatory markers including the growth factor YKL-40 by immunoassays (ELISA). Integrated analyses were performed to identify cellular and humoral patterns with potential impact on tissue regeneration.

Results: Posttraumatic levels of circulating white blood cells, immature progenitor subsets and platelets as well as YKL-40, IL-6 and CRP varied biphasic and correlated to type of traumas.

Analytic MFC identified two minor $C D 45^{\text {neg }}$ blood compartments which simultaneously expressed varying degrees of CD105, CD133, CD73, VEGF-R, CD144, or CD31, CD34, CD166, CXCR4, respectively, supporting that mesenchymal subsets are involved in fracture healing.

Analysis by microarray identified posttraumatic significant changes in gene expression of specific genes with known relation to inflammation, bone regeneration and angiogenesis in circulating mononuclear cells (MNC).

ELISA quantitation of YKL-40 revealed posttraumatic changes higher in hip traumas compared to patients with ankle fractures (MNC: $p=0.0006$; YKL-40: $p=0.0004$ ). YKL-40 also correlated to the type of bone trauma, documented by different levels in patients with planned surgical hip replacements and traumatic hip fractures $(p=0.005)$.

Conclusions: The present study describes a posttraumatic time dependent cellular and humoral response after planned hip replacements, ankle and hip fractures. The data identify and enumerate potential mesenchymal progenitor cells supporting a regenerative role. Finally the analysis documented a correlation between the growth factor YKL-40 and bone traumas separating it from IL-6 and CRP. These observations can be used to future identification, isolation and characterization of circulating cells with impact in bone regeneration.

Keywords: Biomarkers; Bone regeneration; Fracture; Gene expression; Mesenchymal progenitor cells; YKL-40

\section{Introduction}

Bone fracture results in cell death, local ischemia, formation of a fracture haematoma and secretion of pro-inflammatory cytokines as IL-1, IL-6, IL-8 and TNFa from traumatized periosteum, macrophages and inflammatory cells locally and in the circulation. This inflammatory stage initiates a cytokine mediated repair cascade with a chemotactic effect on inflammatory cells, enhancing extra cellular matrix synthesis, stimulating angiogenesis and recruiting endogenous fibrinogenic cells to the fracture site. A subsequent stage involves angiogenesis stimulated by VEGF, PDGF and angiopoietin, meanwhile a soft cartilage containing callus replaces the fracture haematoma. From about day 7 committed osteoprogenitors in the periosteum undergo intramembranous ossification, which is the formation of new bone. During this regenerative stage the fracture site is divided into a central cartilage containing zone and a peripheral bone containing zone. The zone division of the callus is partly due to the distance from the vascularised fracture ends and periosteum to the mesenchymal progenitor cells, which influence whether these cells differentiate into bone or cartilage through changes in $\mathrm{pH}$-levels and oxygen tension. The following stages of endochondral ossification in the central zone of the fracture haematoma involves hardening of the callus by cartilage calcification, in growth of new blood vessels, cartilage removal by apoptosis and finally bone formation. Cytokines as IL-1, IL-6, RANKL,

*Corresponding author: Hans E Johnsen MD DMSc, Professor, Clinical Haematology, Aalborg Hospital Science and Innovation Centre (AHSIC), Aarhus University Hospital, Sdr. Skovvej 15, DK-9000 Aalborg Denmark, Tel: +45 993268 75 (Office), +45 411800 53(Mobile); E-mail: haej@rn.dk

Received September 16, 2011; Accepted November 10, 2011; Published November 12, 2011

Citation: Gottlieb H, Klausen TW, Boegsted M, Olsen BS, Lausten GS, et al. (2011) A Clinical Study of Circulating Cellular and Humoral Biomarkers Involved in Bone Regeneration Following Traumatic Lesions. J Stem Cell Res Ther 1:108 doi:10.4172/2157-7633.1000108

Copyright: @ 2011 Gottlieb H, et al. This is an open-access article distributed under the terms of the Creative Commons Attribution License, which permits unrestricted use, distribution, and reproduction in any medium, provided the original author and source are credited. 
OPG and TNFa also regulate the later endochondral bone remodeling [1-5].

At the fracture site mesenchymal progenitor cells are attracted and stimulated by the micro environment withholding growth factors such as TGF $\beta$, PDGF, BMP, IGF-1 and -2 to differentiate into bone or cartilage cells [5-8]. Mesenchymal progenitor cells are a compartment of inactive, non-haematopoietic mononuclear cells with the potential ability to differentiate into several types of mature cells as chondrocytes, osteoblasts and endothelial cells. Such mesenchymal progenitor cells have been isolated from many tissues e.g. bone marrow, fat, muscle, skin and peripheral blood [8-12]. Mesenchymal progenitors are released from the bone marrow to the fracture site by the circulation, and the formation of new blood vessels infiltrating the calcified callus is a limiting step for bone regeneration $[1,2,13,14]$.

Fracture regeneration has several similarities with prenatal bone development, which has lead to the idea that differentiation of mesenchymal progenitor cells is a congenital ability, (re-)activated by certain evolutionary basic humeral signals after tissue traumas [12,1520]. The central role of IL- 6 in bone regeneration is underlined by high concentrations of this cytokine during inflammation [2-5,15,21-23], but IL- 6 has also been documented to influence and quantify the later ossification [21,24-26].

C-reactive protein (CRP) is an acute phase protein produced by the liver under transcriptional control of IL-6 [27]. CRP has been reported to peak the second day after fracture and normalize by the third week $[23,28]$. CRP quantifies the type of bone trauma, treatment and postoperatively complications as deep wound infection or bronchopneumonia [29-32].

YKL-40 (also named chitinase-3-like-1 and human cartilage glycoprotein-39) is a heparin-, chitin- and collagen-binding lectin and a member of "mammalian chitinase-like proteins". YKL-40 is produced by human embryonic stem cells (unpublished), embryonic- and fetal cells, [20], arthritic chondrocytes, inflammatory cells and endothelial cells. The full biological functions of YKL-40 are still unknown, but it is a growth factor for chondrocytes and fibroblasts, it modulates the rate of type I collagen fibril formation, and has been suggested to play a role in cell proliferation and differentiation, angiogenesis, inflammation and in remodelling of the extra cellular matrix. The YKL-40 expression rises after cartilage trauma in arthritic joints and is related to the initial repair response [33-39]. Serum YKL-40 increases rapidly after a malleolar or tibia fracture followed by a decrease after osteosynthesis [40].

The observation that solid tissues are colonized by organ-specific circulating blood cells suggests that organ specific tissue regeneration and repair may be feasible if we learn to regulate progenitor cells from the circulating blood into areas of injured or diseased tissue and to modulate maturation once these cells have reached the target tissue. The basic humoral mechanisms that lead to formation of bone are known but the cellular components are still not completely understood. Therefore, translational research, including clinical studies needs to be performed to develop cellular treatment strategies.

In this descriptive report we have focused on a clinical in vivo model for bone regeneration following traumatic bone fracture or lesions studied by a multiparametric approach integrating data from cytomics, genomics and proteomics. The objective of the study was to identify temporal changes of important circulating subsets involved in bone regeneration - guided by analysis of known humeral biomarkers.

\section{Patients, Materials and Methods}

\section{Patient inclusions and exclusions}

The experimental protocol was approved by the regional scientific ethical committee in Copenhagen (Number KA 05081). All patients received oral and written information and participated under signed informed consent.

A total of sixty-two patients were primary included in two prospective cohorts admitted to the Orthopaedic Department from 2005 to 2007 with an ankle- or hip fracture (cohort 1) or a planned hip replacement due to osteoarthritis (cohort 2). The hip fractures were all located at the femoral neck and were all operated with the same technique, which in short consists of a thick stabilizing screw in the femoral neck, supported by a plate on the lateral side of the femur. The material is placed through a lateral sharp approach through the skin. Patients with planned hip replacements all had osteoarthritis and all were operated in the same way with a cement fixated total hip prosthesis, which was placed by access through the gluteus muscle.

Patients with multiple fractures, severe cardiopulmonary disease, and surgery within 6 months or malignancy were excluded. Demographical data were registered from medical records included age, sex, type of bone damage, complications and co-morbidity (Table $1)$.

The study was prospectively planned and conducted but extended due to initial experiences including: i) failed attempts to perform flow cytometry analyses of surface markers of frozen cells (data not shown), ii) lack of plasma samples within the first 24 hours following fracture, iii) no presurgical baseline value before planned hip replacements, iv) minor cellular responses following ankle fractures.

Patients in cohort 2 were consecutively included under the same criteria as patients in cohort 1, but with additional samples 3-5 and 1215 hours after fracture and a presurgery sample taken before planned hip replacements.

Of 37 patients included in cohort 1, five patients were later excluded (1 patient with ankle fracture refused to participate, 2 patients with hip fractures died, 1 had dementia and 1 had two fractures at a later examination). This resulted in 13 patients with ankle fractures, 10 patients with hip fractures and 9 patients with planned hip replacement (Table 1). Of 25 patients included in cohort 2 , seven patients were later excluded ( 2 patients had diagnosed cancer, 1 refused to participate because of religion, and 4 patients died). This resulted in 10 patients with planned hip replacements and 8 patients with hip fracture. In summary a total of 50 patients completed the study periods and include the study cohorts. We further included 17 healthy controls with the same age as the fracture patients (Table 1). The healthy controls did not have surgery, severe cardiovascular morbidity or known malignancy within 6 months of inclusion.

\section{Design, material and methods}

Cohort $1(\mathrm{~N}=32)$ had blood sampled day 1, 3, 7, 14, 21, 28, 42 and 84 days after bone trauma. Cohort $2(\mathrm{~N}=18)$ samples were collected before operation, 3-5 hours and 12-15 hours after bone lesion with additionally blood samples taken after trauma as for cohort 1 . Blood samples were drawn into $5 \mathrm{x} 10 \mathrm{ml}$ ethylenediaminetetraacetic acid (EDTA) stabilized tubes. Serum was isolated from $10 \mathrm{ml}$ blood in one $10 \mathrm{ml}$ Serum Sep Clot Activator glass.

Between $1 / 2-3$ hours after vein puncture stabilized blood samples 
Citation: Gottlieb H, Klausen TW, Boegsted M, Olsen BS, Lausten GS, et al. (2011) A Clinical Study of Circulating Cellular and Humoral Biomarkers Involved in Bone Regeneration Following Traumatic Lesions. J Stem Cell Res Ther 1:108. doi:10.4172/2157-7633.1000108

Page 3 of 10

\begin{tabular}{|c|c|c|c|c|c|c|c|}
\hline \multirow[t]{2}{*}{ Bone trauma } & \multirow{2}{*}{$\begin{array}{l}\text { No. of pt. } \\
\text { in./ex./ } \\
\text { completed }\end{array}$} & \multirow{2}{*}{$\begin{array}{l}\text { Age/ years } \\
\text { range }\end{array}$} & \multirow[t]{2}{*}{ Sex } & \multicolumn{2}{|c|}{ Co-morbidity } & \multirow{2}{*}{$\begin{array}{l}\text { Complications affecting } \\
\text { bone regeneration }\end{array}$} & \multirow{2}{*}{$\begin{array}{l}\text { Total \# } \\
\text { Blood samples }\end{array}$} \\
\hline & & & & total & diagnoses & & \\
\hline AF & $14 / 1 / 13$ & $\begin{array}{l}47 \\
(22-68)\end{array}$ & $7 \mathrm{M} 6 \mathrm{~F}$ & $2 / 13$ & $2 \mathrm{RD}$ & $3 / 13$ & 8 \\
\hline HF (1) & $14 / 4 / 10$ & $\begin{array}{l}77 \\
(60-89)\end{array}$ & $5 \mathrm{M} 5 \mathrm{~F}$ & $5 / 10$ & $\begin{array}{l}1 \mathrm{GI}, \mathrm{ND}, \mathrm{t} . \mathrm{CP} \\
1 \mathrm{RD}, \mathrm{OP}, \mathrm{t} . \mathrm{ED} \\
1 \mathrm{OP} \\
1 \mathrm{OP}, \mathrm{t} . \mathrm{CP}, \mathrm{ND} \\
1 \mathrm{AS}\end{array}$ & $6 / 10$ & 8 \\
\hline THR (1) & 9/9 & $70(44-84)$ & $2 \mathrm{M} 7 \mathrm{~F}$ & $\begin{array}{l}\text { 9/9 OA } \\
3 / 9 \mathrm{nOA}\end{array}$ & $\begin{array}{l}1 \mathrm{HT} \\
1 \mathrm{OP}, \mathrm{RD}, \mathrm{t} . \mathrm{CP} \\
1 \mathrm{RD}\end{array}$ & $1 / 9$ & 8 \\
\hline HF (2) & $13 / 5 / 8$ & $85(75-90)$ & $8 \mathrm{~F}$ & $7 / 8$ & $\begin{array}{l}1 \mathrm{DE} \\
1 \mathrm{t} . \mathrm{CP} \\
1 \mathrm{OP} \\
1 \mathrm{DE} \\
1 \mathrm{OP}, \mathrm{t} . \mathrm{ED}, \mathrm{RD} \\
1 \mathrm{HP}, \mathrm{RD} \\
1 \mathrm{ND}, \mathrm{DE}\end{array}$ & $2 / 8$ & 10 \\
\hline THR (2) & $12 / 2 / 10$ & $68(50-80)$ & $2 \mathrm{M} 8 \mathrm{~F}$ & $\begin{array}{l}\text { 10/10 OA } \\
6 / 10 \mathrm{nOA}\end{array}$ & $\begin{array}{l}1 \text { t.CP } \\
1 \text { t.CP } \\
1 \text { t.CP } \\
1 \text { HP, t.ED } \\
1 \mathrm{HP}, \mathrm{t} . \mathrm{ED} \\
1 \mathrm{HP}\end{array}$ & $1 / 10$ & 9 \\
\hline
\end{tabular}

AF - ankle fracture, HF - hip fracture, THR - Total hip replacement. OA - osteo arthritis, t.CP - treated cardiovascular illness, HC - high cholesterol, t.ED - treated endocrine disease, DE - dementia, OP - osteo porosis, RD - rheumatoid disease, HP - high blood pressure, nOA - non osteo arthritic disease, GI - Gastro intestinal disease, ND - Neurological disease, AS - Artery sclerosis,

Table 1: Demographic and clinical data included age, sex, type of bone damage, complications and co-morbidity.

were processed into mononuclear cells (MNC) from the pooled EDTA-blood in T75 flasks $\left(\mathrm{Nunc}^{\mathrm{TM}}\right)$ that was centrifuged in portions of $15 \mathrm{ml}$ diluted blood 1:2 in PBS (137 mM NaCl, $2.7 \mathrm{mM} \mathrm{KCl}, 1.4$ $\mathrm{mM} \mathrm{NaH} \mathrm{PO}_{4} \cdot \mathrm{H}_{2} \mathrm{O}, 6.5 \mathrm{mM} \mathrm{NA}_{2} \mathrm{HPO}_{4} \cdot 2 \mathrm{H}_{2} \mathrm{O}, \mathrm{pH}$ 7.3-7.4; Hospital pharmacy, Copenhagen, Denmark) on $10 \mathrm{ml}$ Lymphoprep in $50 \mathrm{ml}$ Leucosep ${ }^{\star}$ filter glasses (Greiner bio-one, Germany) at $2100 \mathrm{rpm}, 10$ minutes. The interface containing primarily mononuclear cells (MNC) were harvested and washed with PBS twice.

Isolated MNCs from patients in cohort 1 and 2 were counted and subsequently frozen in 95\% fetal bovine serum (FBS) and 5\% dimethyl sulfoxide (DMSO) in $1.8 \mathrm{ml}$ tubes containing $1 \mathrm{ml}$ with $10^{7}$ cells per $\mathrm{ml}$ at $-80^{\circ} \mathrm{C}$ as described previously $[41,42]$. Fresh isolated MNCs from patients in cohort 2 were analysed by multi parametric flow cytometry as described below.

\section{Enumeration of blood cells and subsets}

Full blood leucocytes (WBC) and platelets were enumerated on a "Bechman Coulter AC-T diff 2" before preparation of MNC. The expected number of MNC in blood were calculated from the concentration of WBC and fraction of granulocytes $(\mathrm{G})$ by $\mathrm{MNC}=$ WBC $10^{9} / \mathrm{L} \times(1-\mathrm{G})$.

MNC subsets were identified and enumerated by multi parametric flow cytometry (MFC) analysis. A number of $1 \times 10^{7}$ cells were washed in FACS-PBS+10\% FBS with EDTA. The cell pellet was incubated 30 minutes with the panel of highly selected $\mathrm{CD}$ specific antibodies given in Table 2 coupled by a range of cytochromes consisting of fluorescein isothiocyanate (FITC), r-phycoerythrin (PE), peridinin chlorophyll protein (PerCP) and allophycocyanin (APC). Antibody conjugated cells were then washed once with FACS-PBS + 10\% NCS + EDTA to remove unbound antibody. A panel of monoclonal antibodies, including anti-CD45 to exclude haematopoietic cells and anti-CD31,
-CD34, -CD73, -CD105, -CD133, -CD166, -CD144, -VEGFR-2 and -CXCR4 (CD184) to differentiate by appropriate analysis gates were used to identify and enumerate mesenchymal cell subsets. All the antibodies were conjugated to the cells simultaneously.

The remaining cell pellet was mixed with $350 \mu \mathrm{l}$ FACS-PBS + $10 \%$ NCS + EDTA and applied for analysis by a four colour flow cytometry (FACS Calibur, BD bioscience). Antibody marked MNC were gated in a forward-/side scatter dot plot (region 1). The strict CD $45^{\text {neg }}$ cells were defined (region 2). Cells in region 1 and 2 were considered to be strict $\mathrm{CD} 45^{\text {neg }}$ non-haematopoietic cells with low granularity. The $\mathrm{CD} 45^{\text {neg }}$ cells were subsequently analyzed for presence

\begin{tabular}{|l|l|l|l|}
\hline Associated cell population & $\begin{array}{l}\text { Cluster of } \\
\text { differentiation }\end{array}$ & Molecule & Conjugation \\
\hline Leukocytic common antigen & CD45 & LCA & PerCP \\
\hline Haematopoietic progenitor cell & CD34 & $\begin{array}{l}\text { Glycoprotein } \\
105-120\end{array}$ & APC \\
\hline Haematopoietic progenitor cell & CD133 & AC133 & PE \\
\hline Mesenchymal progenitor cell & CD73 & $\begin{array}{l}\text { Ecto-5'- } \\
\text { nucleotidase }\end{array}$ & PE \\
\hline Mesenchymal progenitor cell & CD105 & Endolgin & FITC \\
\hline Mesenchymal progenitor cell & CD166 & ALCAM & PE \\
\hline Endothelial cells & CD31 & PECAM-1 & FITC \\
\hline Endothelial progenitor cell & CD144 & VE-cadherin & FITC \\
\hline & VEGFR-2 & VEGFR-2 & PE \\
\hline Injured and hypoxic tissue & CD184 & CXCR4 & PE \\
\hline Negative control & IgG1(Mouse) & & all \\
\hline
\end{tabular}

Table 2: The panel of selected CD specific antibodies used to identify and enumerate subpopulations by multiparametric flow cytometry (MFC). 
of other membrane CD markers given in Table 2 and enumerated following subtraction of the corresponding negative controls. After acquisition of at least 50000 cells per PB sample, analyses were considered as informative when adequate numbers of events $(>100$, typically 3-400) were collected in the enumeration gates.

Absolute cell numbers were calculated by reference leucocyte counts and healthy controls persons had a circulating level of nonhaematopoietic cells identified as CD $45^{\text {neg }}$ of $0.66 \times 10^{9} / \mathrm{L}\left(0.3 \times 10^{9} / \mathrm{L}-\right.$ $\left.1.2 \times 10^{9} / \mathrm{L}\right)$.

The concentration of subsets was performed by a two step calculation: first, the fraction of CD45 $5^{\text {neg }} \mathrm{MNC}(\%) \mathrm{x}$ blood concentration of MNC $\left(10^{9} / \mathrm{L}\right)=$ blood level of $\mathrm{CD} 45^{\text {neg }} 10^{\%} / \mathrm{L}$ and second, this level of CD $45^{\text {neg }}$ $10^{9} / \mathrm{L} \times \mathrm{CD} \%=$ blood level of a non haematopoietic CD subset.

\section{Gene expression analysis by Micro array technique}

Global gene expression profiling was performed on thawed circulating MNCs taken i) from 6 patients before operation, day 7 and 42 after planned hip replacements and ii) from 6 patients 3-5 hours, day 7 and 42 after hip fractures.

Micro array analysis was performed on isolated MNC lysed with Trizol (Invitrogen Trizol ${ }^{\circledR}$ Reagent Cat. No. 15596-026) and total RNA was purified on columns (MirVana ${ }^{\mathrm{Tw}}$, miRNA isolation Cat. No.1561 Ambion). With a Poly-A-tail accepting primer, a cDNA strand was synthesised. A T7 RNA polymerase was used to generate the biotin labelled cRNA via an in vitro transcription (GeneChip Expression 3 '-Amplification Reagents for IVT Labelling, Affymetrix). $3 \mu \mathrm{g}$ isolated total RNA was amplified and resulted in $25 \mu$ biotin labelled cRNA, from which $20 \mu \mathrm{g}$ were put in a hybridization cocktail and placed on HGU $133+2.0$ Affymetrix gene chips. The gene chips were read on a scanner and expression data stored as .cel-files in a data base.

The subsequent analysis was performed using Bioconductor packages [43] which are add-on modules for the statistical package $\mathrm{R}$, (R Development Core Team, 2004).

As we experienced that the two treatment groups have considerably variations in their gene-expression patterns over time, we choose to normalise and analyse the three data-sets separately. Only in this way we are sure to maintain interesting time variations in each group during normalization. A batch effect across the treatment groups was noticed. We adjusted for this effect by centralising each group towards the grand mean of all probes.

The quality of the raw data was inspected by RNA-degradation plots and histograms for each patient by routines from the Bioconductor package array Quality Metrics [44]. No slides showed poor quality (data not shown).

Background correction and normalisation was carried out by the Robust Multichip Average procedure (RMA) found in the Bioconductor package "affy" [45]. We made an unspecific prefiltering for the hip fracture and hip prosthesis groups with nsFilter from the Bioconductor package gene filter. This procedure considerably brought down the number of probes. No filtering of the healthy control group was performed as this group acts as control in later comparisons.

For each treatment group a linear mixed effects model was fitted to the logarithm of the gene expressions, with patients modelled as a random effect to take into account the inter-person correlation. Time was modelled as a fixed effect. The Bioconductor package Limma [46] was used to fit the model. Differentially expressed genes between time points were identified by consideration of moderated $t$-tests for relevant contrasts. The moderated t-test is based on empirical Bayes analysis, and is equivalent to shrinkage of estimated sample variances towards a pooled estimate, resulting in more stable inference when the number of micro array experiments is small. Due to the high number of false positives introduced because of multiple testing, we used the Benjamini-Hochberg (BH) q-values to control or estimate the false discovery rate. The meaning of "BH" q-values is as follows. If all genes with q-value below a threshold, say 0.005 , are selected as differentially expressed, then the expected proportion of false discoveries in the selected group is controlled to be less than the threshold value, in this case $0.5 \%$.

Comparisons between the hip fractures and hip prosthesis groups versus the healthy control group were performed by heat maps. We used the heamap.2 function from the R-package gplots. The hierarchical cluster analysis indicated in these heat maps was based on the R-function hclust using average as the agglomeration method and Euclidian distance as dissimilarity measure.

\section{Biomarker YKL-40, IL-6 and CRP analysis}

Samples were analyzed without clinical knowledge of the patients. Serum concentrations of YKL-40 and IL- 6 were determined by Enzyme-Linked Immuno Sorbent Assay (ELISA) (YKL-40: Quidel, CA, USA; IL-6: Quantikine HS, high sensitivity, R\&D Systems, Oxon, UK) in accordance with the manufacturer's instructions. The detection limit for YKL-40 was $20 \mu \mathrm{g} / \mathrm{l}$, and the intra- and inter-assay coefficient of variations (CVs) were $<5 \%$ and $<6 \%$, respectively. The detection limit for IL- 6 was $0.17 \mathrm{ng} / \mathrm{l}$, and the intra- and inter-assay CVs were $<6.6 \%$ and $<8.9 \%$, respectively. All samples and standards were analysed in duplicates, and samples from each patient were analyzed on the same ELISA plate. Three (IL-6) and two (YKL-40) internal control samples were analysed on each plate to confirm assay precision.

The reference interval for serum YKL-40 and IL- 6 were determined in healthy subjects with no signs of pre-existing disorders such as joint, liver, metabolic or endocrine disease or malignancy and no medication. The median serum YKL-40 in 245 healthy adults ( 134 women and 111 men, median age 49 , range 18 to 79 years) was $43 \mu \mathrm{g} / \mathrm{l}$ (range 20 - 184 $\mu \mathrm{g} / \mathrm{l}$; 5 th - 95th percentile: 20 - $124 \mu \mathrm{g} / \mathrm{l})$. The median serum IL-6 in 318 healthy adults ( 122 women and 196 men, median age 47, range 18 to 64 years) was $1.4 \mathrm{ng} / \mathrm{l}$ (range $0.25-22.5 \mathrm{ng} / \mathrm{l}$; 5th - 95th percentile: $0.51-4.92 \mathrm{ng} / \mathrm{l})$.

Serum concentrations of C-reactive protein (CRP) was analysed on a KONELAB 60 apparatus that measures immune complexes with turbidimetry at $340 \mathrm{~nm}$ in accordance with the manufacturer's instructions. The antibody supplier is Dakota Cytomation, Glostrup, Denmark. The lower measuring limits are $3 \mathrm{mg} / \mathrm{L}$ for normal CRP and $0.2 \mathrm{mg} / \mathrm{L}$ for high sensitive C-reactive protein (hs-CRP). Intra-assay $\mathrm{CV}$ was $6.3 \%$. Serum CRP values from $0-90 \mathrm{mg} / \mathrm{L}$ were measured using the hs-CRP method. Serum CRP values from $>90 \mathrm{mg} / \mathrm{L}$ were measured using the normal CRP method. CRP values $<10 \mathrm{mg} / \mathrm{l}$ is considered normal.

\section{Statistical analysis}

The statistical calculations were done by SPSS (SPSS statistical software system, version 17.0, Chicago, IL, USA) and R (R project for statistical computing, version 2.8.0, Vienna, Austria). All tests were two-sided and p-values less than 0.05 were considered significant. 
Skewed variables were log transformed to obtain normality when needed.

Comparison between groups was done by t-test or Mann-Whitney's test when the normality assumption was violated and comparison within groups were done by paired t-test or Wilcoxon's signed rank test when the normality assumption was violated.

Variations over several time points were calculated by a mixedeffect model, using the $\mathrm{R}$ package nlme. The time/visit variable was treated as a factor / ordinal variable.

Correlations were calculated using Spearman's rho test. The mean values of serum YKL-40, -IL6 and -CRP during the 12 weeks study were calculated as the area under the curve (AUC) values and using 8 time points for patients in cohort 1 (i.e. at baseline and after 1, 3, 7, 14, $21,28,42$, and 84 days), 9 time points for patients with planned total hip replacements- and 10 time points for patients with hip fractures in cohort 2. Since YKL-40 increases with age an age-related reference interval was calculated on the logarithmically $(\log )$ transformed YKL40 values of the healthy controls [35]. The $95 \%$ percentile was chosen as the cut-off point.

\section{Results}

\section{Blood counts following fracture and during regeneration}

The number of circulating leucocytes and platelets changed during bone regeneration as did non haematopoietic cells defined as CD $45^{\text {neg }}$ MNCs with an initial reduction followed by a rise day 1-2 and an overshoot in the following week (Figure $1 \mathrm{~A}$ and B).
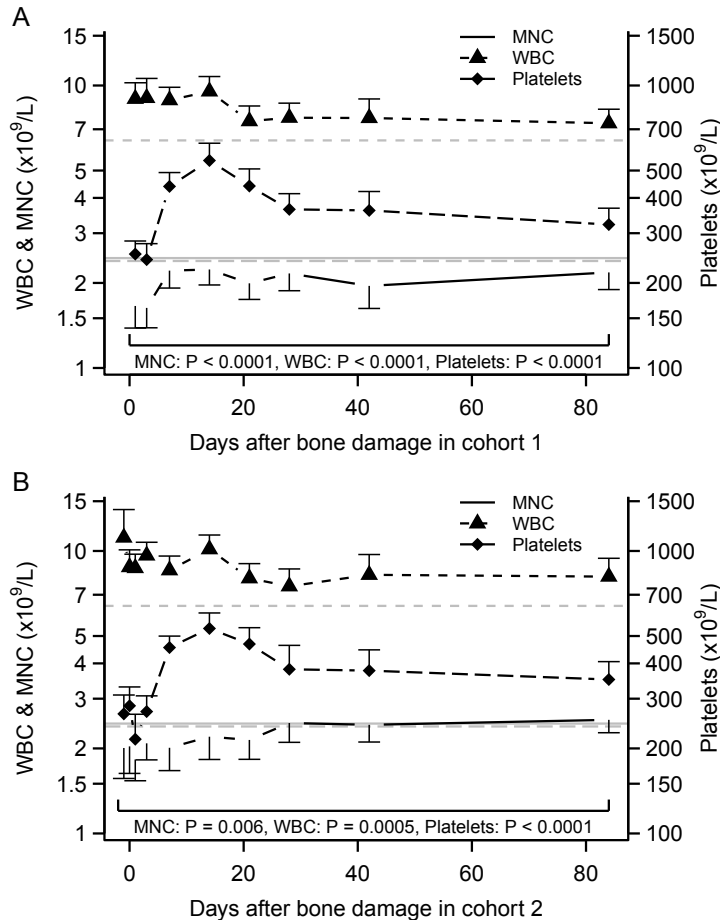

Figure 1: Quantification of circulating leucocytes (WBC), mononuclear cells (MNC) and platelets in cohort 1 are shown in figure $1 \mathrm{~A}$ and cohort 2 is shown in figure 1B. Healthy controls had an average age of 71 years (63-81) and a mean number of circulating leucocytes of $6.53 \times 10^{9} / \mathrm{L}\left(4.1 \times 10^{9} / \mathrm{L}-8.8 \times 10^{9} / \mathrm{L}\right)$, MNC of $2.53 \times 10^{9} / \mathrm{L}\left(1.19 \times 10^{9} / \mathrm{L}-3.57 \times 10^{9} / \mathrm{L}\right)$. Levels for healthy controls are grey lines in the figures.

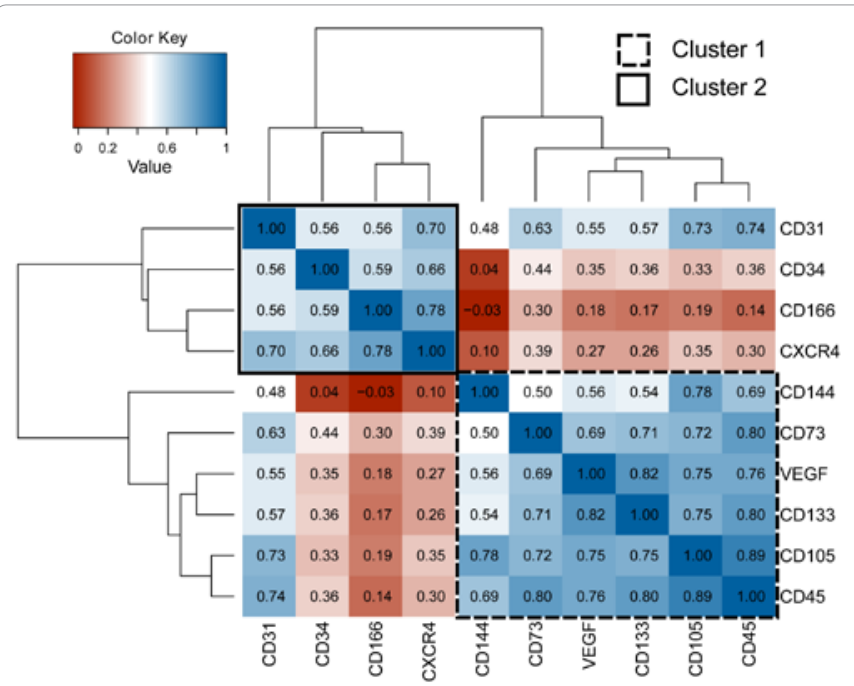

Figure 2: The CD45 neg MNCs clusters in two subpopulations according to the changing intensities of the specific surface markers during bone regeneration. The underlined and dotted squares illustrate the division of the surface markers in respectively cluster 1 and cluster 2 according to their internal correlations. The numbers in the squares are the correlation coefficients, which are also explained in the colour key.

\section{Enumeration of non-haematopoietic subpopulations in cir- culation}

MFC analyses of circulating CD $45^{\text {neg }}$ cells in all patients with surgical or traumatic bone traumas revealed the phenotype of two homogeneous clusters during bone regeneration, according to intensities of the specific surface markers given in Figure 2. The underlined and dotted squares illustrate two time correlated clusters (Figure 2).

The CD45 neg/CD73/CD105/CD144 ${ }^{\text {pos }}$ (cluster 1) declined sharply the first day after bone trauma in patients with planned hip replacements or hip fractures, indicating a posttraumatic extra vascular outflow from the circulating blood into reactive areas. The cells in cluster 1 peaked earlier in patients with hip fractures than in patients with planned hip replacements, followed by a plateau from day 21 to 84 in both groups (Figure 3A-D), possibly due to different regenerative responses in the two patient groups.

The level of CD45 neg/CD31/CD34/CD166/CXCR4pos (cluster 2) cells were higher in patients with planned hip replacements than in patients with hip fractures throughout the study period $(\mathrm{p}=0.049$, $\mathrm{p}=0.002, \mathrm{p}=0.02$ and $\mathrm{p}=0.047$ ) (Figure 4A-D).

\section{Micro array gene expression in circulating MNC}

With a false discovery rate (FDR) at $0.5 \%, 1462$ genes changed expressions levels in MNCs from day 1 to 7 after hip fractures. A total of 1456 genes changed expression levels when comparing day 1 with day 42 after hip fracture.

A heat map (Figure 5) including the most varying genes in MNCs from hip fractures and healthy controls illustrate how the expression changes during the first 24 hours after the fracture and then normalizes towards the pre-fracture homeostatic equivalence, during the initial 42 days after the trauma. Even though the numbers of genes that changed expression level from day 1 to day 7 and 42 respectively were almost similar, the functional clustering of the up- or down regulated genes 
Citation: Gottlieb H, Klausen TW, Boegsted M, Olsen BS, Lausten GS, et al. (2011) A Clinical Study of Circulating Cellular and Humoral Biomarkers Involved in Bone Regeneration Following Traumatic Lesions. J Stem Cell Res Ther 1:108. doi:10.4172/2157-7633.1000108

differed (Table 3 and 4). Gene clusters of inflammation, cellular activity and cellular stress played a more important role day 7 , than day 42. This is documented by higher EASE-scores of the clusters correlated to bone regeneration at day 7 than at day 42 and lower p-values of the related sub-clusters. The EASE-scores (enrichment-score) of 1.3 is equivalent to a non-log scale 0.05 , meaning that attention should be given towards gene-clusters with EASE-scores $>1.3$. The key-cluster of "Tissue healing" was not significantly present at day 42 compared to day 7 (Table 3 and 4 ).
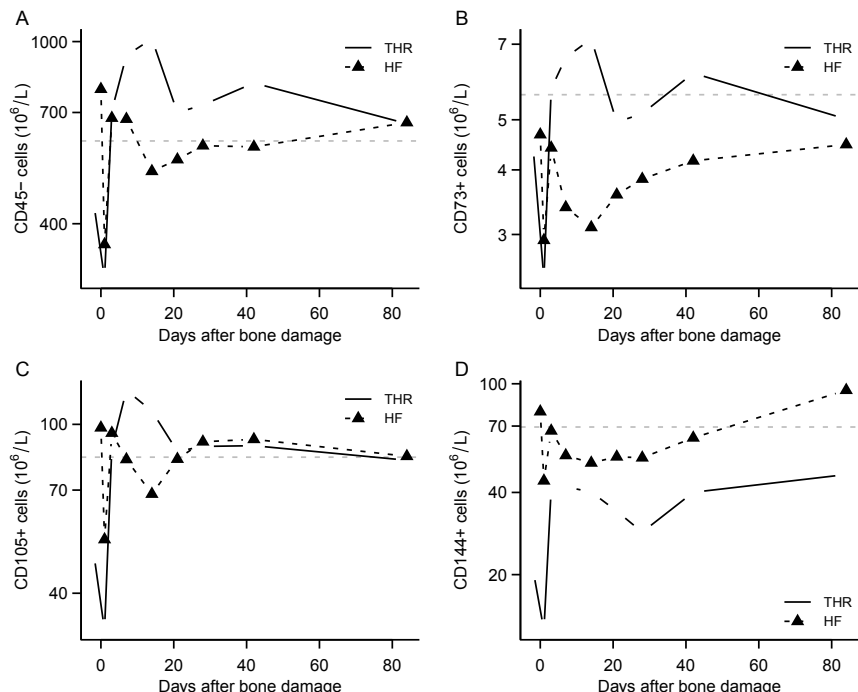

Figure 3: Show changes during bone regeneration in $C D 45^{\text {neg }} \mathrm{MNC}(\mathrm{A})$, CD73 pos, CD45 ${ }^{\text {neg }}$ MNC (B), CD105 ${ }^{\text {pos }}$, CD45 neg MNC (C), CD144 pos CD45neg MNC (D) (Cluster 1). The initial drop is underlined by $p$-values. The grey line shows the level of the specific surface marker in healthy subjects.
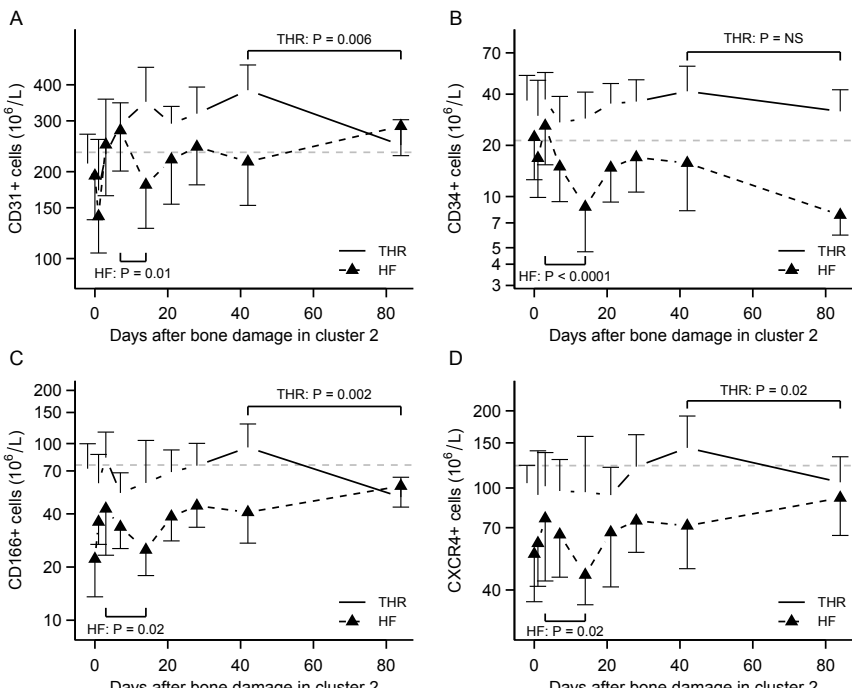

Figure 4: Show changes during bone regeneration in CD31 $1^{\text {pos }}, C D 45^{\text {neg }} \mathrm{MNC}$ (A), CD34 ${ }^{\text {pos }}, C^{2} 45^{\text {neg }}$ MNC (B), CD166 ${ }^{\text {pos }}$, CD45 ${ }^{\text {neg }} \mathrm{MNC}(\mathrm{C})$ and CXCR4 $4^{\text {pos }}$ CD45 ${ }^{\text {neg }}$ MNC (D) (Cluster 2). The decline at day 14 of all the surface markers on cells in cluster 2 , which are only seen in patients with hip fractures, is documented by $p$-values in the figure. The grey line shows the level of the specific surface marker in healthy subjects.

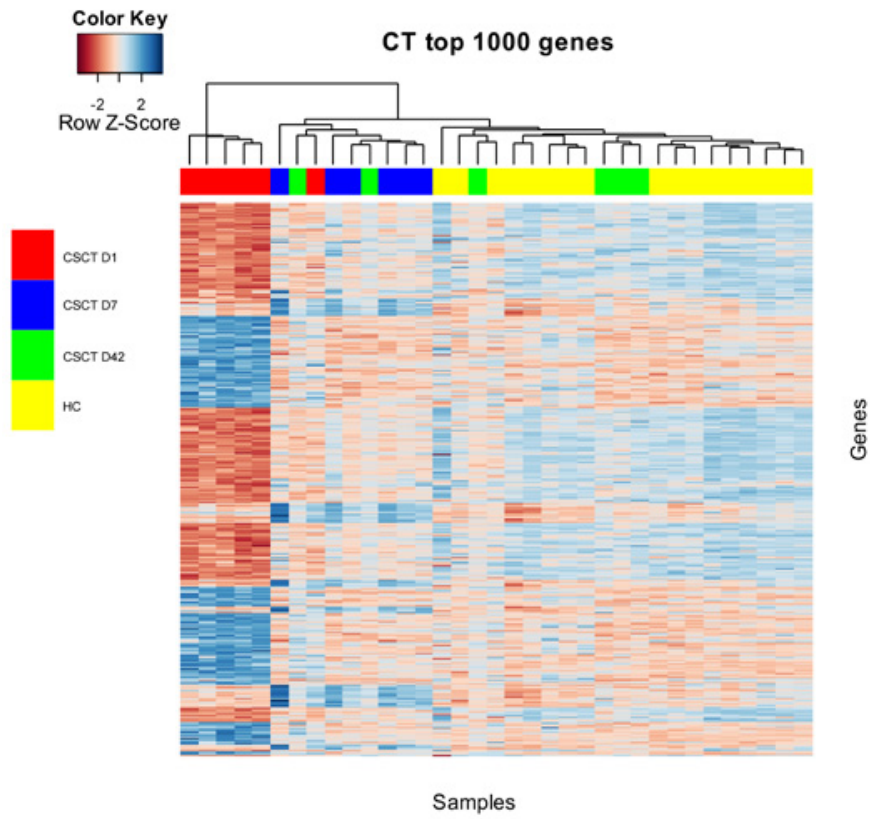

Figure 5: The heat map shows the standardised values of the 1000 most time-varying genes. Red bars mean an up regulation of the gene and blue bars mean a down regulation of the gene. The genes are row-wise sorted by a cluster algorithm according to their similarity with other genes. Likewise are the samples column-wise sorted by a cluster algorithm according to their similarity with other samples. The coloured squares between the dendrogram and the heat map indicate the time point of the collection: Columns under red squares are taken 3-5 hours after fracture (D1), columns under blue squares are taken at day 7 after fracture, columns under green squares are taken at day 42 after fracture and columns under yellow squares are from healthy subjects. The genetic expression changes during bone regeneration from very aberrant at 3-5 hours after fracture, towards almost normal at day 42

\section{Serum biomarkers following fracture and during regeneration}

Patients with hip fractures or planned hip replacements had higher serum YKL-40 concentrations than patients with ankle fractures (median $710 \mu \mathrm{g} / \mathrm{l}$, range $102-1478 \mu \mathrm{g} / \mathrm{l}$ vs. $77 \mu \mathrm{g} / \mathrm{l}, 38-345 \mu \mathrm{g} / \mathrm{l}$, $\mathrm{P}=0.0004)$ from day $1-7$. YKL-40 increased after trauma in patients with hip fractures $(\mathrm{P}=0.0001)$ and after surgery in patients who got planned hip replacements $(\mathrm{P}<0.0001)$ (Figure 6A and $8 \mathrm{~B}$ ).

Serum IL-6 rose during day 1 after planned surgery or fracture $(\mathrm{P}<0.0001)$ and declined in a similar pattern in all three patient groups, indicating that IL- 6 quantifies the same posttraumatic inflammatory process (Figure 6C and 8D). IL-6 were higher at day 1 in patients with hip fractures or planned hip replacements, than in patients with ankle fractures $(\mathrm{P}<0.0001)$. This indicates a relation between IL- 6 and the magnitude of the traumatized bone (Figure $6 \mathrm{C}$ ). There were no differences in IL-6 levels in patients with hip fractures or planned hip replacements, during early bone regeneration between day 14 and 42 $(\mathrm{P}=0.4)$, which indicates that IL-6 does not differ according to the type of bone trauma, in contrast to YKL-40..

Changes in s-CRP are known to quantify ongoing inflammation as IL-6. CRP rose posttraumatic $(\mathrm{P}<0.0001)$, but with a significant difference between patients with traumatic hip fractures or planned hip replacement and patients with ankle fractures $(\mathrm{P}=0.0021)$ (Figure $6 \mathrm{E}$ ). Posttraumatic changes in s-CRP were considerable in patients with hip fractures $(\mathrm{P}<0.0001)$ and patients with planned hip replacements 
Citation: Gottlieb H, Klausen TW, Boegsted M, Olsen BS, Lausten GS, et al. (2011) A Clinical Study of Circulating Cellular and Humoral Biomarkers Involved in Bone Regeneration Following Traumatic Lesions. J Stem Cell Res Ther 1:108. doi:10.4172/2157-7633.1000108

Page 7 of 10

\begin{tabular}{|c|c|c|c|}
\hline Key cluster & EASE-score & Sub-cluster & $\begin{array}{l}\text { P-value } \\
\text { (Benjamini) }\end{array}$ \\
\hline \multirow[t]{2}{*}{$\begin{array}{l}\text { Transcription } \\
\text { binding }\end{array}$} & 5.7 & Transcription factor binding & $4.4 \mathrm{E}-6$ \\
\hline & & Transcription cofactor activity & $7.5 \mathrm{E}-4$ \\
\hline \multirow[t]{3}{*}{ Apoptosis } & 4.86 & Regulation of apoptosis & 1.7E-5 \\
\hline & & Cell development & 1.6E-2 \\
\hline & & Cell differentiation & 3.3E-1* \\
\hline \multirow[t]{5}{*}{ Cellular stress } & 4.00 & Response to stress & 3.1E-6 \\
\hline & & Response to wounding & 3.6E-3 \\
\hline & & Response to external stimulus & $5.9 \mathrm{E}-2$ \\
\hline & & Defense response & $2.0 \mathrm{E}-1$ \\
\hline & & Inflammatory response & $4.5 \mathrm{E}-1$ \\
\hline Cell cycle & 3.8 & Regulation of cell cycle & 3.7E-3 \\
\hline \multirow[t]{2}{*}{$\begin{array}{l}\text { Intracellular } \\
\text { transport }\end{array}$} & 3.76 & Golgi vesicle transport & $2.5 \mathrm{E}-4$ \\
\hline & & $\begin{array}{l}\text { ER to Golgi vesicle-mediated } \\
\text { transport }\end{array}$ & $1.1 \mathrm{E}-2$ \\
\hline Biotic stimulus & 2.57 & Response to biotic stimulus & 3.8E-2 \\
\hline \multirow[t]{6}{*}{ Tissue healing } & 2.08 & Wound healing & $9.1 \mathrm{E}-2$ \\
\hline & & Hemostasis & $1.2 \mathrm{E}-1$ \\
\hline & & Blood coagulation & 1.7E-1 \\
\hline & & Regulation of body fluid levels & $3.5 \mathrm{E}-1$ \\
\hline & & Platelet activation & $4.9 \mathrm{E}-1$ \\
\hline & & $\begin{array}{l}\text { Complement and coagulation } \\
\text { cascades }\end{array}$ & 8.8E-1 \\
\hline
\end{tabular}

* correlated to "cell development" $(\mathrm{k}=0.87)$

Table 3: Key- and sub-clusters of genes associated to the ongoing posttraumatic inflammation or bone regeneration. The genes are differentially expressed at day 1 and day 7 in patients with hip fractures.

\begin{tabular}{|c|c|c|c|}
\hline Key cluster & EASE-score & Sub-cluster & $\begin{array}{l}\text { P-value } \\
\text { (Benjamini) }\end{array}$ \\
\hline \multirow[t]{2}{*}{$\begin{array}{l}\text { Transcription } \\
\text { binding }\end{array}$} & 3.25 & Transcription factor binding & 3.0E-2 \\
\hline & & Transcription cofactor activity & $6.1 \mathrm{E}-2$ \\
\hline \multirow[t]{3}{*}{ Apoptosis } & 2.29 & Regulation of apoptosis & $2.8 \mathrm{E}-1$ \\
\hline & & Cell development & $6.8 \mathrm{E}-1$ \\
\hline & & Cell differentiation & $9.9 \mathrm{E}-1$ \\
\hline \multirow[t]{5}{*}{ Cellular stress } & 0.56 & Response to stress & $1.0 \mathrm{E}-2$ \\
\hline & & Response to wounding & $9.9 \mathrm{E}-1$ \\
\hline & & Response to external stimulus & $5.2 \mathrm{E}-1$ \\
\hline & & Defense response & $9.3 \mathrm{E}-1$ \\
\hline & & Inflammatory response & 9.7E-1 \\
\hline Cell cycle & 3.15 & Regulation of cell cycle & $2.9 \mathrm{E}-2$ \\
\hline \multirow[t]{2}{*}{$\begin{array}{l}\text { Intracellular } \\
\text { transport }\end{array}$} & 3.31 & Golgi vesicle transport & $6.3 \mathrm{E}-3$ \\
\hline & & $\begin{array}{l}\text { ER to Golgi vesicle-mediated } \\
\text { transport }\end{array}$ & 3.0E-2 \\
\hline Biotic stimulus & 1.5 & Response to biotic stimulus & $5.2 \mathrm{E}-1$ \\
\hline \multirow[t]{6}{*}{ Tissue healing } & None & Wound healing & - \\
\hline & & Hemostasis & - \\
\hline & & Blood coagulation & - \\
\hline & & Regulation of body fluid levels & - \\
\hline & & Platelet activation & - \\
\hline & & $\begin{array}{l}\text { Complement and coagulation } \\
\text { cascades }\end{array}$ & - \\
\hline
\end{tabular}

Table 4: Key- and sub-clusters of genes associated to the ongoing posttraumatic inflammation or bone regeneration. The genes are differentially expressed at day 1 and day 42 in patients with hip fractures.

\begin{tabular}{|l|l|l|l|l|}
\hline Hip fractures in patients day 7 vs. 1 HF (7vs1) \\
\hline Gene-ID & log FC & adj. P. Val (BH) & Gene list & Gene function \\
\hline 210512_s_at & $-2,01066$ & 0,00038 & VEGFA & Angiogenesis \\
\hline 202337_at & $-0,70716$ & 0,00049 & PMF1 & Osteogenesis \\
\hline 205207_at & $-0,59814$ & 0,017 & IL6 & Inflammation \\
\hline 209201_x_at & $-1,14702$ & 0,027 & CXCR4 & Stem cell attraction \\
\hline 203085_s_at & 0,642476 & 0,042 & TGFB1 & Osteogenesis \\
\hline Hip fracture in patients day 42 vs. 1 HF (42vs1) & & \\
\hline Gene-ID & log FC & adj. P. Val (BH) & Gene list & Gene function \\
\hline 210512_s_at & $-2,10542$ & 0,00022 & VEGFA & Angiogenesis \\
\hline 202337_at & $-0,59411$ & 0,0028 & PMF1 & Osteogenesis \\
\hline 205207_at & $-0,61017$ & 0,014 & IL6 & Inflammation \\
\hline 209201_x_at & $-1,28274$ & 0,017 & CXCR4 & Stem cell attraction \\
\hline & & & & \\
\hline
\end{tabular}

Table 5: Identification of Benchmark-genes expressed in blood MNC from hip fractured patients.

$(\mathrm{P}<0.0001)$ (Figure 6E and 8F). As seen for IL-6, did CRP not differ in patients with hip fractures or in patients with planned hip replacements, indicating that CRP is unspecific according to the type of hip trauma $(\mathrm{P}=0.13$ and $\mathrm{p}=0.08)$.

\section{Discussion}

Patients with traumatic hip or ankle fractures regenerate through intra-membranous and endochondral ossification, in contrast to patients with total hip replacements due to osteoarthritis, who have their implants fixated through cementation with a minor amount of bone formation and risk of aseptic loosening of the prosthesis [47-49]. It is the hypothesis of this research project that extended knowledge of fracture pathophysiology may allow us to predict the quality of repair mechanisms and risk of side effect of therapy.

The present knowledge of bone repair mechanisms and the pathophysiology of fracture healing are mainly based on animal studies. Differences in the anatomy and metabolism of animals and humans are limitations in the transfer of experimental data from animal models into clinical situations. Therefore, the present research project addresses a human clinical model with special emphasis on the time dependent involvement of circulating mesenchymal progenitor cells and humoral biomarkers in bone repair $[4,5,7,22]$.

The specific aims of this study was to measure the initial and later changes of the number of specific compartments of mononuclear cells and levels of IL-6, CRP and YKL-40 in peripheral blood following bone injuries in two prospective cohorts including 50 patients, with ankle- or hip fracture (cohort 1) or planned hip replacements (cohort 2) compared to age matched healthy controls.

The work plan included timely collected blood sampling during the post traumatic period and analysis for i) non-haematopoietic $\left(\mathrm{CD} 45^{\text {neg }}\right)$ mesenchymal subsets by multiparametric flow cytometry (MFC), ii) global gene expression profiling (GEP) by micro array and iii) serum inflammatory markers including the growth factor YKL40 by immunoassays (ELISA). Subsequent integrated analyses were performed to identify cellular and humoral patterns with potential impact on tissue regeneration - for future isolation and characterization. 
First, multiparametric flow cytometry analyses of circulating MNCs revealed two homogeneous clusters of $\mathrm{CD} 45^{\text {neg }}$ MNCs (Figure 2). The two clusters were defined by similar changes over time for specific surface makers. One cluster consisted of CD45 ${ }^{\text {neg }}$ MNCs with presence of the surface markers CD73, CD105 and CD144, which are known to be associated with mesenchymal progenitor cells $[8,50,51]$. The second cluster consisted of CD45 ${ }^{\text {neg }}$ MNCs with presence of the surface markers CD31, CD34, CD166 and CXCR4. The surface markers CD31 and CD34 are associated with mature endothelial- and endothelial progenitor cells, which are involved in neo-angiogenesis [52,53]. Reperfusion of the ischemic fracture haematoma is of utmost importance for of blood born mesenchymal progenitor cells. CD166 is associated to mesenchymal progenitor cells and cell adhesion $[54,55]$. CXCR4 is a chemokine receptor present on MNCs, which are drawn towards traumatized or ischemic tissue, because of the secretion of SDF-1 (stromal cell derived factor 1) from such tissues[19,56]. The presence of specific surface markers on cells within the same cluster indicates a similar and related role in regeneration of traumatized- and ischemic bone.

Second, extended microarray analyses of the posttraumatic circulating MNCs identified a set of up- or down regulated genes involved in bone regeneration, inflammatory and neo-angiogenesis. The magnitude of the posttraumatic changes in the gene lists from
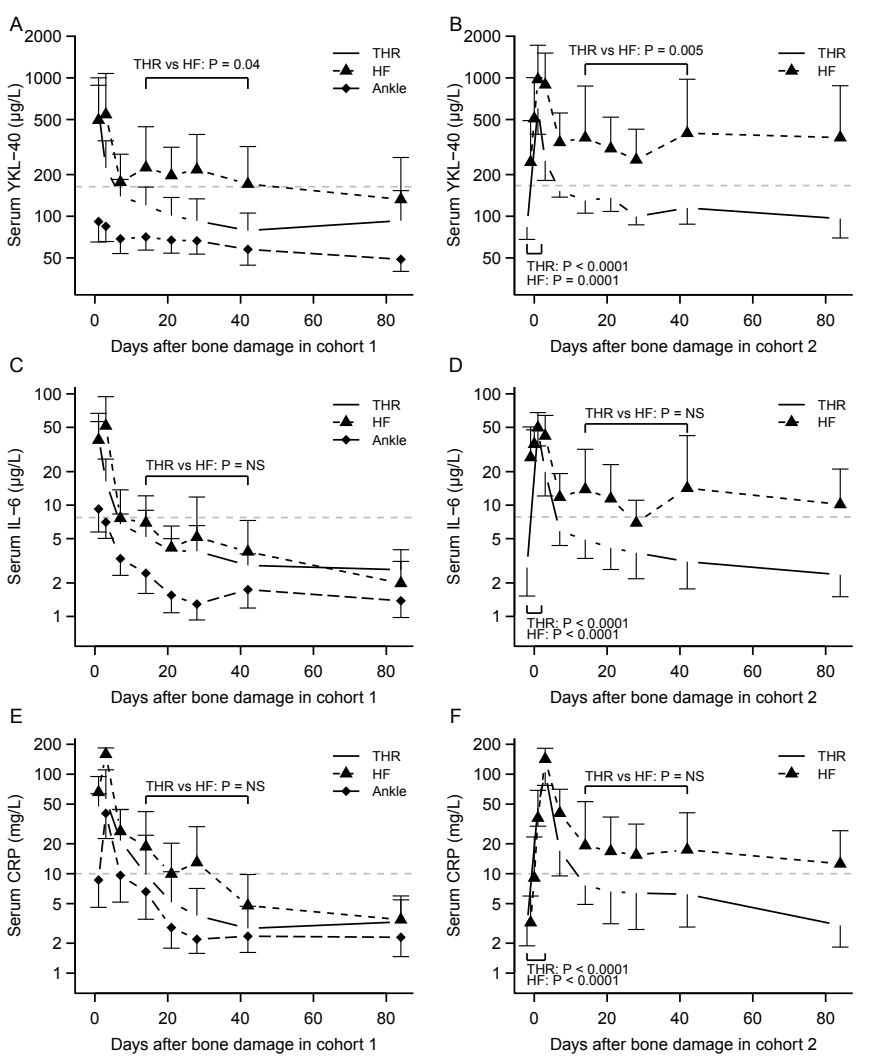

Figure 6: Figure $6 \mathrm{~A}, 6 \mathrm{C}$ and $6 \mathrm{E}$ shows changes of $\mathrm{YKL}-40$, IL-6 and $\mathrm{CRP}$ in patients in cohort 1. Figure 6B, 6D and $6 \mathrm{~F}$ shows changes of $Y K L-40, I L-6$ and $\mathrm{CRP}$ in patients in cohort 2. Dotted grey lines mark upper boundaries of normal levels of the cytokines. The initial rise in all the cytokines within the first day in patients with hip fractures are documented by $p$-values for patients in cohor 2 at the bottom of the figure. The elevated levels of YKL-40 from day 14-42 in patients with hip fractures compared to patients with total hip replacements in cohort 1 and 2 are documented by $p$-values at the top of figures $6 \mathrm{~A}$ and $6 \mathrm{~B}$. day 7 and 42, together with the pattern of gene expression, which goes from highly abnormal towards normal homeostasis during the first 42 days after fracture, also support the trauma-related role of the circulating MNCs (Figure 5). The functional role and involvement of circulating MNCs in actual bone regeneration, inflammation and neoangiogenesis are further indicated by the functional cluster analysis of the up- or down regulation of certain benchmark genes within the gene lists at day 7 and 42 (Table 5) [57,58].

Third, the humoral inflammatory response that we quantified through serum levels of YKL-40, IL- 6 and CRP, correlated significantly to the magnitude of traumatized bone, documented by larger posttraumatic changes in YKL-40, IL-6 and CRP in patients with hip fractures or planned hip replacements than in patients with ankle fractures. The higher level of YKL-40 during initial bone formation from day 14 to 42 in patients with hip fractures than in patients with planned hip replacements may indicate that YKL-40 is a quantitative marker of endochondral ossification, independent of age. YKL-40, in contrast to IL- 6 and CRP, correlated to both the type and magnitude of bone traumas, which again underlines a more central role involvement in actual bone formation, which separates it from the other inflammatory markers. The faster post traumatic decline towards normal YKL-40 values, in patients with planned hip replacements than in patients with hip fractures, could be due to the lesser bone regeneration after cement fixation than after traumatic bone fracture, caused by the chemical toxicity and heat generation of the bone cement (Figure 6A) [59-61].

Though IL- 6 has been shown to be involved in bone mineralization and remodelling in rats and that elevation on IL- 6 , also in rats, has an adverse effect on bone regeneration, we did not see any correlation between type of hip trauma and IL-6 [21,24-26].

In conclusion, this report describes the nature and concentration of posttraumatic circulating progenitor cell compartments, identifies reactive genes and functional clusters of these expressed in circulating mononuclear cells and involved inflammatory and regenerative biomarkers YKL-40, IL-6, and CRP during regeneration of surgical and traumatic bone traumas. This clinical in vivo model will be used to identify, isolate and characterize the potential mesenchymal progenitor cell compartment, analyses of specific gene expression for future functional preclinical studies.

\section{Acknowledgement}

This study has been granted by Danish Rheumatism Association, The Research Council at Herlev Hospital, Aase and Ejnar Danielsen Foundation Göran Bauers Grant, The Illum foundation, The Tvermoes'ske generation- and family foundation, Doctors insurance association of 1891/Tryg insurance, The Osteoporosis foundation research fund, Director Jacob Madsen and Wife Olga Madsens Foundation, Carl and Ellen Hertzs grant for Danish medical science, Spar Nord Foundation, E Willumsen Foundation and Obelske Family Foundation.

The authors thank Eva Gaarsdal, Kirsten Nikolajsen and Ann-Maria Jensen for technical assistance.

\section{References}

1. Einhorn TA (1998) The cell and molecular biology of fracture healing. Clin Orthop Relat Res: S7-21

2. Gerstenfeld LC, Cullinane DM, Barnes GL, Graves DT, Einhorn TA(2003) Fracture healing as a post-natal developmental process: molecular, spatial, and temporal aspects of its regulation. J Cell Biochem 88: 873-884

3. Giannoudis PV, Einhorn TA, Marsh D (2007) Fracture healing: the diamond concept. Injury 38 Suppl 4: S3-S6.

4. Phillips AM (2005) Overview of the fracture healing cascade. Injury 36 Suppl 3 S5-S7. 
Citation: Gottlieb H, Klausen TW, Boegsted M, Olsen BS, Lausten GS, et al. (2011) A Clinical Study of Circulating Cellular and Humoral Biomarkers Involved in Bone Regeneration Following Traumatic Lesions. J Stem Cell Res Ther 1:108. doi:10.4172/2157-7633.1000108

5. Tshamala M, van $\mathrm{BH}$ (2006) Osteoinductive properties of the bone marrowmyth or reality. Vet Comp Orthop Traumatol 19: 133-141.

6. Devine MJ, Mierisch CM, Jang E, Anderson PC, Balian G (2002) Transplanted bone marrow cells localize to fracture callus in a mouse model. J Orthop Res 20: $1232-1239$

7. Forriol F, Shapiro F (2005) Bone development: interaction of molecular components and biophysical forces. Clin Orthop Relat Res: 14-33.

8. Kuznetsov SA, Mankani MH, Gronthos S, Satomura K, Bianco P, et al. (2001) Circulating skeletal stem cells. J Cell Biol 153: 1133-1140.

9. Eghbali-Fatourechi GZ, Lamsam J, Fraser D, Nagel D, Riggs BL, et al. (2005) Circulating osteoblast-lineage cells in humans. N Engl J Med 352: 1959-1966.

10. Jiang Y, Jahagirdar BN, Reinhardt RL, Schwartz RE, Keene CD, et al. (2002) Pluripotency of mesenchymal stem cells derived from adult marrow. Nature 418: 41-49.

11. Pittenger MF, Mackay AM, Beck SC, Jaiswal RK, Douglas R, et al. (1999) Multilineage potential of adult human mesenchymal stem cells. Science 284 : 143-147.

12. Wan C, He Q, Li G (2006) Allogenic peripheral blood derived mesenchymal stem cells (MSCs) enhance bone regeneration in rabbit ulna critical-sized bone defect model. J Orthop Res 24: 610-618.

13. Street J, Bao M, deGuzman L, Bunting S, Peale FV, et al. (2002) Vascula endothelial growth factor stimulates bone repair by promoting angiogenesis and bone turnover. Proc Natl Acad Sci U S A 99: 9656-9661.

14. Street JT, Wang JH, Wu QD, Wakai A, McGuinness A, et al. (2001) The angiogenic response to skeletal injury is preserved in the elderly. J Orthop Res 19: $1057-1066$

15. Dimitriou R, Tsiridis E, Giannoudis PV (2005) Current concepts of molecular aspects of bone healing. Injury 36: 1392-1404.

16. Ferguson C, Alpern E, Miclau T, Helms JA (1999) Does adult fracture repair recapitulate embryonic skeletal formation? Mech Dev 87: 57-66.

17. He Q, Wan C, Li G (2007) Concise review: multipotent mesenchymal stromal cells in blood. Stem Cells 25: 69-77.

18. Johansen JS, Hoyer PE, Larsen LA, Price PA, Mollgard K (2007) YKL-40 protein expression in the early developing human musculoskeletal system. $J$ Histochem Cytochem 55: 1213-1228.

19. Kucia M, Jankowski K, Reca R, Wysoczynski M, Bandura L, (2004) CXCR4SDF-1 signalling, locomotion, chemotaxis and adhesion. J Mol Histol 35: 233245

20. Laursen SB, Mollgard K, Olesen C, Oliveri RS, Brochner CB (2007) Regional differences in expression of specific markers for human embryonic stem cells. Reprod Biomed Online 15: 89-98.

21. Beloosesky Y, Hendel D, Weiss A, Hershkovitz A, Grinblat J, et al. (2007) Cytokines and $\mathrm{C}$-reactive protein production in hip-fracture-operated elderly patients. J Gerontol A Biol Sci Med Sci 62: 420-426.

22. Giannoudis PV, Smith MR, Evans RT, Bellamy MC, Guillou PJ (1998) Serum CRP and IL- 6 levels after trauma. Not predictive of septic complications in 31 patients. Acta Orthop Scand 69: 184-188.

23. Yoon SI, Lim SS, Rha JD, Kim YH, Kang JS, et al. (1993) The C-reactive protein (CRP) in patients with long bone fractures and after arthroplasty. Int Orthop 17: 198-201.

24. Yang X, Ricciardi BF, Hernandez-Soria A, Shi Y, Pleshko CN, et al. (2007) Callus mineralization and maturation are delayed during fracture healing in interleukin-6 knockout mice. Bone 41: 928-936.

25. Rozen N, Lewinson D, Bick T, Jacob ZC, Stein H, et al. (2007) Fracture repair: modulation of fracture-callus and mechanical properties by sequential application of IL-6 following PTH 1-34 or PTH 28-48. Bone 41: 437-445.

26. Miller RR, Cappola AR, Shardell MD, Hawkes WG, Yu-Yahiro JA, et al. (2006) Persistent changes in interleukin-6 and lower extremity function following hip fracture. J Gerontol A Biol Sci Med Sci 61: 1053-1058.
27. Pepys MB, Hirschfield GM (2003) C-reactive protein: a critical update. J Clin Invest 111: 1805-1812.

28. Ellitsgaard N, Andersson AP, Jensen KV, Jorgensen M 1991 Changes in C-reactive protein and erythrocyte sedimentation rate after hip fractures. Int Orthop 15: 311-314.

29. Neumaier M, Metak G, Scherer MA (2006) C-reactive protein as a parameter of surgical trauma: CRP response after different types of surgery in 349 hip fractures. Acta Orthop 77: 788-790.

30. Neumaier M, Scherer MA (2008) C-reactive protein levels for early detection of postoperative infection after fracture surgery in 787 patients. Acta Orthop 79 428-432.

31. Okafor B, MacLellan (1998) Postoperative changes of erythrocyte sedimentation rate, plasma viscosity and $\mathrm{C}$-reactive protein levels after hip surgery. Acta Orthop Belg 64: 52-56

32. Scherer MA, Neumaier M, von GS (2001) C-reactive protein in patients who had operative fracture treatment. Clin Orthop Relat Res: 287-293.

33. Conrozier T, Carlier MC, Mathieu P, Colson F, Debard AL, et al. (2000) Serum levels of YKL-40 and $C$ reactive protein in patients with hip osteoarthritis and healthy subjects: a cross sectional study. Ann Rheum Dis 59: 828-831.

34. Garnero P, Piperno M, Gineyts E, Christgau S, Delmas PD, et al. (2001) Cross sectional evaluation of biochemical markers of bone, cartilage, and synovia tissue metabolism in patients with knee osteoarthritis: relations with disease activity and joint damage. Ann Rheum Dis 60: 619-626.

35. Jacques C, Recklies AD, Levy A, Berenbaum F (2007) HC-gp39 contributes to chondrocyte differentiation by inducing SOX 9 and type II collagen expressions. Osteoarthritis Cartilage 15: 138-146.

36. Johansen JS, Hvolris J, Hansen M, Backer V, Lorenzen I (1996) Serum YKL-40 levels in healthy children and adults. Comparison with serum and synovial fluid levels of YKL-40 in patients with osteoarthritis or trauma of the knee joint. $\mathrm{Br} J$ Rheumatol 35: 553-559.

37. Johansen JS, Stoltenberg M, Hansen M, Florescu A, Horslev-Petersen K, et al. (1999) Serum YKL-40 concentrations in patients with rheumatoid arthritis: relation to disease activity. Rheumatology (Oxford) 38: 618-626.

38. Kawasaki M, Hasegawa $Y$, Kondo S, Iwata H (2001) Concentration and localization of YKL-40 in hip joint diseases. J Rheumatol 28: 341-345

39. Volck B, Johansen JS, Stoltenberg M, Garbarsch C, Price PA, et al. (2001) Studies on YKL-40 in knee joints of patients with rheumatoid arthritis and osteoarthritis. Involvement of YKL-40 in the joint pathology. Osteoarthritis Cartilage 9: 203-214

40. Stoffel K, Engler H, Kuster M, Riesen (2007) Changes in biochemical markers after lower limb fractures. Clin Chem 53: 131-134.

41. Beshlawy AE, Metwally HG, Khalek KA, Hammoud RF, Mousa SM (2009) The effect of freezing on the recovery and expansion of umbilical cord blood hematopoietic stem cells. Exp Clin Transplant 7: 50-55.

42. Skoric D, Balint B, Petakov M, Sindjic M, Rodic P (2007) Collection strategies and cryopreservation of umbilical cord blood. Transfus Med 17: 107-113.

43. Gentleman RC, Carey VJ, Bates DM, Bolstad B, Dettling M, et al. (2004) Bioconductor: open software development for computational biology and bioinformatics. Genome Biol 5: R80.

44. Kauffmann A, Gentleman R, Huber W (2009) arrayQualityMetrics--a bioconductor package for quality assessment of microarray data. Bioinformatics 25: 415-416.

45. Irizarry RA, Hobbs B, Collin F, Beazer-Barclay YD, Antonellis KJ, et al. (2003) Exploration, normalization, and summaries of high density oligonucleotide array probe level data. Biostatistics 4: 249-264.

46. Smyth GK (2004) Linear models and empirical bayes methods for assessing differential expression in microarray experiments. Stat Appl Genet Mol Biol 3 . Article3.

47. Holt G, Murnaghan C, Reilly J, Meek RM (2007) The biology of aseptic osteolysis. Clin Orthop Relat Res 460: 240-252. 
Citation: Gottlieb H, Klausen TW, Boegsted M, Olsen BS, Lausten GS, et al. (2011) A Clinical Study of Circulating Cellular and Humoral Biomarkers Involved in Bone Regeneration Following Traumatic Lesions. J Stem Cell Res Ther 1:108. doi:10.4172/2157-7633.1000108

48. Koulouvaris P, Ly K, Ivashkiv LB, Bostrom MP, Nestor BJ, et al. (2008) Expression profiling reveals alternative macrophage activation and impaired osteogenesis in periprosthetic osteolysis. J Orthop Res 26: 106-116.

49. Lenz R, Mittelmeier W, Hansmann D, Brem R, Diehl P (2009) Response of human osteoblasts exposed to wear particles generated at the interface of total hip stems and bone cement. J Biomed Mater Res A 89: 370-378.

50. Delorme B, Charbord $P$ (2007) Culture and characterization of human bone marrow mesenchymal stem cells. Methods Mol Med 140: 67-81.

51. Minguell JJ, Fierro FA, Epunan MJ, Erices AA, Sierralta WD (2005) Nonstimulated human uncommitted mesenchymal stem cells express cell markers of mesenchymal and neural lineages. Stem Cells Dev 14: 408-414.

52. Mancuso P, Burlini A, Pruneri G, Goldhirsch A, Martinelli G (2001) Resting and activated endothelial cells are increased in the peripheral blood of cancer patients. Blood 97: 3658-3661.

53. Matsumoto T, Kawamoto A, Kuroda R, Ishikawa M, Mifune $Y$, et al. (2006) Therapeutic potential of vasculogenesis and osteogenesis promoted by peripheral blood CD34-positive cells for functional bone healing. Am J Pathol 169: $1440-1457$.

54. Liu F, Akiyama Y, Tai S, Maruyama K, Kawaguchi Y, et al. (2008) Changes in the expression of CD106, osteogenic genes, and transcription factors involved in the osteogenic differentiation of human bone marrow mesenchymal stem cells. J Bone Miner Metab 26: 312-320.
55. Singh S, Jones BJ, Crawford R, Xiao Y (2008) Characterization of a mesenchymal-like stem cell population from osteophyte tissue. Stem Cells Dev 17: $245-254$.

56. Wojakowski W, Tendera M, Michalowska A, Majka M, Kucia M, et al. (2004) Mobilization of CD34/CXCR4+, CD34/CD117+, c-met+ stem cells, and mononuclear cells expressing early cardiac, muscle, and endothelial markers into peripheral blood in patients with acute myocardial infarction. Circulation 110: 3213-3220.

57. Coussens AK, Hughes IP, Wilkinson CR, Morris CP, Anderson PJ, et al. (2008) Identification of genes differentially expressed by prematurely fused human sutures using a novel in vivo - in vitro approach. Differentiation 76: 531-545.

58. Martin TJ, Quinn JM, Gillespie MT, Ng KW, Karsdal MA, et al. (2006) Mechanisms involved in skeletal anabolic therapies. Ann N Y Acad Sci 1068: 458-470.

59. Horowitz SM, Doty SB, Lane JM, Burstein AH (1993) Studies of the mechanism by which the mechanical failure of polymethylmethacrylate leads to bone resorption. J Bone Joint Surg Am 75: 802-813.

60. Vale FM, Castro M, Monteiro J, Couto FS, Pinto R, et al. (1997) Acrylic bone cement induces the production of free radicals by cultured human fibroblasts. Biomaterials 18: 1133-1135.

61. Zoulgami M, Lucas A, Briard P, Gaude J (2001) A self-setting single-component calcium phosphate cement. Biomaterials 22: 1933-1937. 